\title{
Anti-Semitic Propaganda and the Christian Church in Hitler's Germany: A Case of Schrödinger's Cat
}

\author{
Angelo Nicolaides \\ School of Business Leadership, University of South Africa, Midrand, South Africa \\ Email: nicola@unisa.ac.za
}

How to cite this paper: Nicolaides, A. (2018). Anti-Semitic Propaganda and the Christian Church in Hitler's Germany: A Case of Schrödinger's Cat. Advances in Historical Studies, 7, 1-14. https://doi.org/10.4236/ahs.2018.71001

Received: December 5, 2017

Accepted: March 13, 2018

Published: March 16, 2018

Copyright $\odot 2018$ by author and Scientific Research Publishing Inc. This work is licensed under the Creative Commons Attribution International License (CC BY 4.0)

http://creativecommons.org/licenses/by/4.0/

Open Access

\begin{abstract}
In his epic Mein Kampf, Adolf Hitler made a point of disparaging the intelligentsia. He asserted that propaganda was the most effective tool to use in political campaigns since especially the popular masses generally possessed limited astuteness and were generally devoid of intellect. This article examines the part played by Nazi propaganda in bolstering the National Socialist cause and how it netted the German youth. Nazi indoctrination nurtured racial hatred and resulted in especially vitriolic anti-Semitism. The policy of Gleichschaltung (coordination) brought state governments, professional bodies, German political parties and a range of cultural bodies under the Nazi umbrella, thus education, legal systems and the entire economy became "captured" entities. Germany became dominated by the effective propaganda machine via which virtually all aspects of life was dictated. In this, the Protestant church played a huge part. An analogy is drawn with Erwin Schrödinger's Cat paradox, according to which a macroscopic entity can be simultaneously alive and dead. Thus while people believed they were alive in Nazism, they were in essence dead from a human consciousness perspective even if they were adherents of the Protestant and Catholic churches due to the effectiveness of the propaganda machinery.
\end{abstract}

\section{Keywords}

Hitler, Nazism, Propaganda, Brainwashing, Indoctrination

\section{Introduction and Methodology}

The research philosophy for this article was interpretivistic in that the social world is constructed and given its meaning subjectively by individuals. The work is also descriptive in that the researcher describes and defines the subject and al- 
lows for the drawing of inferences. The researcher embarked on a critical review study relating to desk research of conceptual studies that include relevant issues in Nazi Germany. Numerous scholarly sources and open public domain website sources were consulted to acquire relevant and related articles and there was also wider reading of literary sources from other germane studies, including academic dissertations, and related Historical academic journals.

In 1933, Adolf Hitler, the leader of the National Socialist German Workers' Party (NSDAP - Nazi Party) was elected as the Chancellor of Germany. He almost instantaneously began laying the fundamentals of the Nazi State which he had introduced in his book Mein Kampf, (My Struggle) which was penned during the post Great War years. The book has two parts and the first part was written by Hitler while he was in incarcerated in Landsberg prison due to his failed Munich putsch (coup d'état) attempt in 1923. Hitler wrote the second part after his release from prison in 1925. Hitler dedicated three chapters of Mein Kampf, which was a propaganda instrument, to the study and practice of propaganda (Welch, 1993). Hitler described inter alia his vision of a greater German Reich and how he believes the Jews should be dealt with. Millions of copies of the book which were freely disseminated at civil registry offices as a propaganda exercise after Hitler's assumption of power. Hitler's core was directed by racially prejudiced and dictatorial principles (Allen, 1984).

Mein Kampf states the design of later Nazi propaganda efforts. Hitler states in Chapter VI:

"Propaganda must always address itself to the broad masses of the people. (...) All propaganda must be presented in a popular form and must fix its intellectual level so as not to be above the heads of the least intellectual of those to whom it is directed. (...) The art of propaganda consists precisely in being able to awaken the imagination of the public through an appeal to their feelings, in finding the appropriate psychological form that will arrest the attention and appeal to the hearts of the national masses. The broad masses of the people are not made up of diplomats or professors of public jurisprudence nor simply of persons who are able to form reasoned judgment in given cases, but a vacillating crowd of human children who are constantly wavering between one idea and another. (...) The great majority of a nation is so feminine in its character and outlook that its thought and conduct are ruled by sentiment rather than by sober reasoning. This sentiment, however, is not complex, but simple and consistent. It is not highly differentiated, but has only the negative and positive notions of love and hatred, right and wrong, truth and falsehood" (Murphy, 1939).

Hitler's rise to supremacy in Nazi Germany and the commitment and devotion he enjoyed from the masses was due to the effective use of propaganda by his Minister of Public Enlightenment and Propaganda, Joseph Goebbels (Noakes, 2004: 190). Public opinions, outlooks, and principles were manipulated by what was clearly "brainwashing". Essentially, Germany was placed on a 
course that was Nationalist Socialist in orientation, and the political philosophy of the Nazis, would convert the country into a dictatorial state one-party state (O'Shaughnessy, 2009). The Nazi establishment vigorously promoted its hateful doctrine that infused the very psyche of the German nation. Nazi propagandizing, accused the Jews for Germany's defeat in World War I, and for the harsh terms of the "Diktat" of Versailles. Germany was hoodwinked to the notion that she had suffered from a "stab-in-the-back" inflicted from within Germany by Jewish conspirators supported by left-wing communist collaborators.

Propaganda in Germany was not due to Hitler, Joseph Goebbels, or the Nazis. It was essentially in existence long before the advent of the NSDAP (Coupe, 1998). German propaganda initiatives as well as political satire in reality came to light in the mid-nineteenth century and developed during the Chancellorship of Otto von Bismarck, the "Iron" Chancellor and intensified the defeat of the French forces at the battle of Sedan during the Franco-Prussian war of 1871. Initially, a range of newspapers and other politically oriented organizations published works of propaganda with often opposing political views and sentiments. Once Hitler became Chancellor in 1933, these operations decreased in number and the content of material published was strictly curbed. Hitler resolved to abolish the limited freedom that the press enjoyed (Coupe, 1998: 26). It became imperative for publishing houses which wanted to operate to "tow the Nazi line" and adapt to the vision which Hitler espoused.

Hitler asserted that "Propaganda must not investigate the truth objectively and, in so far as it is favourable to the other side, present it according to the theoretical rules of justice; yet it must present only that aspect of the truth which is favourable to its own side" (Murphy, 1939). Hitler and his cohorts thus persuaded the majority of Germans that the extermination of explicit groups of people was the right course of action to ensure the preservation of the German Herrenvolk or master race. The middle classes were further manipulated as the administration passed the Schriftleitergesetz (Editor's Law), on 4 October 1933. This became the foundation of the Nazi Party's control of the popular press (Hale, 1973) and was critical in driving and promoting the objectives of the NSDAP. The primary revolutionary objective of the NSDAP was the creation of a Volksgemeinschaft (national community) through the extensive use of propaganda (Welch, 2004: 213). Individual freedoms were abolished and society was to technically transcend class distinctions and any religious differences. However, in reality Germany was far removed from these ideals and in essence Nazi Germany became a zombie state as in Schrödinger's Cat, where Nazi supporters were both alive and dead-physically alive but from a human consciousness level, dead.

Hitler's idyllic world advocated the creation of a superior master Aryan race in which other human beings believed to be inferior and deficient in either physical and/or mental purity were to be eliminated. Targets of choice were homosexuals, the mentally and physically disabled, and all Jews, Slavs, and non-whites (Nazi State, 2010). 


\section{Anti-Semitism}

Nazi policies stigmatized populations in Germany who were not ethnic Germans and called for their elimination from society. These included Jews (Semitic people), Romanis (Gypsies), Indians, Slavonic peoples and all other persons of colour who were all deemed to be inferior non-Aryan sub-humans. The Germans as the pure Aryan Herrenvolk (master race) were considered to be the Volksgemeinschaft (people's community) and were at the pinnacle of the social strata (Koonz, 2003; Burleigh \& Wippermann, 1991). Hitler and the Nazi propaganda machinery played on very extensive and long-established German anti-Semitic sentiments. The Jews were invariably held responsible for things such as stealing from the German Volk in the sense of making them work hard while they evaded any physical labour (Beck, 2006). Hitler stated on numerous occasions that the task of the Nazi movement was to crush "Jewish Bolshevism" (Kershaw, 2001). Hitler declared that there were "three vices" related to "Jewish Marxism" namely democracy, pacifism and internationalism, and that the Jews were driving Bolshevism, communism and Marxism (Kershaw, 2001). Hitler made a point of focussing on Germans who were intensely nationalistic in orientation as he realised they would embrace and promote his cause (Hitler, 1971). Thus anti-Semitic propaganda was engrossed on solidifying the German community by demeaning the humanness of Jews and others deemed to be socially, economically and politically undesirable.

The publication entitled Vom deutschen Volk und seinem Lebensraum (On the German People and its Territory) published in 1937, dealt with controversial issues including human inequality, and genetic and racial hygiene. This work sought to stress the vital importance of racial purity, and emphasized the subordination of peoples who were not German. The idea was that such information would mitigate the contamination of Germans by involvement with those of defective genetic composition and diseased genes. Pure blood Germans were required to make the Reich sustainable (Bennecke, 1937, Chapter IV, Para. 2). The importance of German purity was further stressed after The Reichstag Fire Decree of February 28, 1933. This decree allowed for the deferment of even basic civil rights which had been promulgated and guaranteed by the post-Great War Weimar Constitution. Hitler's Third Reich thus converted Germany into a police state. In the process termed Gleichschaltung (co-ordination), the Nazi party began to control all aspects of life.

All civilian organisations, such as agricultural bodies, volunteer organisations, and even sports clubs, where forced to replace their management with Nazi sympathisers and preferably party members. In June 1933, the only the army and the churches were not yet under Nazi control (Evans, 2005). Anti-Semitism became ingrained into the nationalistic collective German psyche and the levels of human consciousness of Germans in general began to diminish. It became a passion to forge a new value system stressing the non-importance of Jews and Communists as such people were believed to challenge the Nazi administration's 
exertions in crafting a flawless Volksgemeinschaft (peoples' community). When speaking at the September 1935 Nazi Party Congress in Nuremberg, Joseph Goebbels associated Bolshevism with international Jewry and cautioned Nazi party members that there was an international Jewish conspiracy which aimed destroying western civilization.

Germans thus lost their most basic rights and the Ordnungspolizei, (Order Police) uniformed police agencies of the Third Reich became a fundamental part of the Schutzstaffel (SS) and police establishment in Nazi Germany. The Gestapo (Geheime Staatspolizei), or Secret State Police created by Hermann Göring in 1933, became the official secret police of Nazi Germany (Miller, 2006). It was especially the Gestapo which played a key role in the Nazi "blueprint" to exterminate the Jews in Europe (Bauz et al., 2013). The renowned Canadian historian Robert Gellately analysed the local offices established in Nazi Germany and concluded that the Gestapo was predominantly comprised of bureaucrats and clerical workers who were contingent upon accusations by citizens for information on the activities of others especially the Jews. The German population was generally more than willing to inform activities which the considered to be at odds with the Nazi vision (Gellately, 1992: 22). The Schutzstaffel exercised great authority through its control of the police. Consequently, all political opponents, such as the Jews, Communists and Social Democrats, were subject to coercion, harassment, and prejudiced laws. Through the application of the Civil Service Law of April 1933, German authorities commenced removing Jews from governmental structures and other national aspects of life and it was considered illegal for Jews to marry Germans who were pure Aryans.

Hitler's dictatorial power resulted in the Führer (supreme leader) principle (Führerprinzip) and this dominated German life in totality. Thus, all authority was vested in the government, the Nazi party, the economy and ultimately family structures. Hitler was to obeyed without and query on his actions and policies (Evans, 2005). Subsequent to the passing of the Nuremberg Laws on Citizenship and Race in 1935, through which Jews lost German citizenship, thousands of Jews emigrated to inter alia Britain and the United states.

Hitler, supported by his henchmen Joseph Goebbels and Reinhard Heydrich strategized to oblige Jews to emigrate. The spark was Kristallnacht (Crystal night also known as the "Night of Broken Glass") which was orchestrated on 9 November, 1938. The media reported that a German diplomat Ernst vom Rath stationed in Paris was murdered by a 17 year old Polish Jewish refugee in Paris by the name of Herschel Grynszpan. A few days prior to the assassination, German authorities had expelled thousands of Jews of Polish citizenship who were living in Germany from the Reich. Grynszpan was dismayed that his parents, who resided in Germany from 1911, were amongst those expelled. Grynszpan's action resulted in a spur-of-the-moment anti-Semitic reaction by the German people.

The consequence was the horrific events of Crystal Night in which well over 7500 Jewish shops were wrecked and looted and 267 synagogues were burnt down by Nazi arsonists. In the violent events over two days, ninety-one Jews 
were slain. However the most horrendous outcome was the fact that roughly 30,000 Jews were sent to concentration camps which were up until that time reserved for only political prisoners. Jewish cemeteries subsequently became specific objects of desecration in many regions of Germany (Gilbert, 2006).

Hugh Carleton Greene, a reporter for The Daily Telegraph described the events in Berlin which was one of the most anti-Jewish cities:

"Mob law ruled in Berlin throughout the afternoon and evening and hordes of hooligans indulged in an orgy of destruction. I have seen several anti-Jewish outbreaks in Germany during the last five years, but never anything as nauseating as this. Racial hatred and hysteria seemed to have taken complete hold of otherwise decent people. I saw fashionably dressed women clapping their hands and screaming with glee, while respectable middle-class mothers held up their babies to see the "fun" (Carleton Greene, 2003).

A small number of Sturm Abteilung (SA Troops) who raped Jewish women on Kristallnacht were arrested because they had raped Jewish women and thus had sexual intercourse with Jews who were non-Aryan and this was contrary to the Nuremberg Laws on sexual intercourse (Schwab, 1990).

Post Kristallnacht thousands of Jews left Germany increased. It has been calculated that from 1933 to 1939, roughly two-fifths of the Jewish population of Germany numbering some 562000 had left the country (Eatwell, 1995: 129). Amongst those fleeing were highly respected Jewish scientists (Pehle, 1991). The Nazi regime barred Jews from schools on November 15 and sanctioned local authorities to enforce curfews. By December 1938, Jews were debarred from most public places in Germany (Friedlander, 1998).

\section{Joseph Goebbels and Anti-Semitism}

The task of propaganda under Goebbels was clear, "its task was to spread the knowledge of National Socialism to the people" (Goebbels, 1934, Para. 27). Thus propaganda was employed as a tool to accomplish Nazi objectives. Thousands of posters and hundreds of films, and countless cartoons, and fliers were disseminated all over Germany which condemned the Jewish community. A notorious films was Der Ewige Jude (The Eternal Jew) directed in 1940 by Fritz Hippler. Taylor (1998: 175) defined the basic precept of the film and stated that "the Jew is an oriental barbarian who has insinuated himself cleverly into European society, and now exploits it parasitically".

The NSDAP commenced passing legislation to relegate Jews and eradicate them from German society in general. For example, The Law for the Restoration of the Professional Civil Service, of 7 April 1933, obliged all non-Aryans to step down from any legal profession job and also from the civil service. Gradually Jews were forced to step down from many other professions and lost their right to practise (Longerich, 2010). Goebbels explained that propaganda is "winning people over to something that [you] have recognized as right," and that "it is the 
forerunner to state control" (Goebbels, 1934, Para. 20).

Propaganda was vital to brainwash the masses that they needed to accept Nazi leadership and conform to the ideology. In 1937, Goebbels asserted at The Great Anti-Bolshevist Exhibition that Bolshevism and Jewry were in essence equally destabilising forces:

"While National Socialism brought about a new version and formulation of European culture, Bolshevism is the declaration of war by Jewish-led international sub-humans against culture itself. It is not only anti-bourgeois, it is anti-cultural. It means, in the final consequence, the absolute destruction of all economic, social, state, cultural, and civilizing advances made by western civilization for the benefit of a rootless and nomadic international clique of conspirators, who have found their representation in Jewry." (Holocaust Encyclopedia, 2017)

From 1933 and 1945, German youth were exposed to virulent anti-Semitic ideology in schools, as well as in the Hitler Jugend (Youth). Radio programmes, printed media, and films also played a huge role in creating hatred against the Jews (Voigtländer \& Voth, 2015). The Nazis endeavoured to replicate the heritage and experiences of Völkisch thought, and they fixated on appealing to the growing sense of national unity which was grounded on the belief in the notion of individuals serving the community. Ultimately, the fixation on racial issues led to the dehumanisation of Jews and others and to the loss of human consciousness by Germans (Snell, 1959).

\section{Protestant Bias}

A longstanding significant belief in Catholicism was that the Jews had crucified Christ, and the protestant reformer Martin Luther passed this belief into Protestantism. Luther believed that the Jews would ultimately convert to Lutheranism as the Protestant Reformation gained ground but this did not happen. Consequently, he wrote strong anti-Semitic discourses, such as The Jews and Their Lies which was written in 1543. Such ideas were thus ingrained in German society (Spielvogel, 2005: 172). During an event held in Königsberg, Erich Koch, who was the Gauleiter of East Prussia, stated that Adolf Hitler and Martin Luther were kindred spirits and he asserted that the Nazis were imbued with Martin Luther's spirit (Steigmann-Gall, 2003).

More recently, Alfons Heck, in his book entitled A Child of Hitler: Germany in the Days When God Wore a Swastika, posits that: "All Catholic children knew that the Jews had killed Christ" (Heck, 1985: 14). Such malicious attitudes were prevalent and common in Nazi Germany. In Der Stürmer, (The Stormer/Attacker/Striker) an unofficial Nazi propaganda tabloid, published by Julius Streicher, Germans were informed that Jews kidnapped small children before Passover because "Jews need the blood of a Christian child, maybe, to mix in with their Matzah". The tabloid was passionately anti-Semitic and often caricatured of Jews and the Roman Catholic Church (Koonz, 2003). 
The Nazi regime piloted key deviations to the Protestant churches in Germany and its leaders buttressed the German Christian movement. This was an assemblage of Protestants who wanted to associate Christianity and National Socialism into a unitary movement which they hoped would exclude all those believed to be impure and embrace all Aryans in a mystical fatherland which was the Third Reich.

The Nazis advised Protestants to unite all regional churches into a stronger national church which fell under the unified leadership of Ludwig Müller, who was a German theologian and leading member of the "German Christians" (German: Deutsche Christen) faith movement. In 1933 he was obligated by the Nazis to accept a role as the Reichsbischof (Reich Bishop) of the Deutsche Evangelische Kirche (German Evangelical Church) which would of course promote Nazism and anti-Semitism (Chandler Robbins, 1938). In line with the Gleichschaltung process, the Nazi leadership would organize each of the separate Protestant regional church bodies into a single and unitary entity, the Reich Church (Reichskirche).

The decisive component of generating pro-Nazi propaganda that would move people to agree with Nazism was simplifying it and giving it "spiritual credibility", thus fashioning a "language of the masses" (Lansen, 2010). German Protestants welcomed these changes and believed propaganda that was replete with simple wording and upfront messages that could be effortlessly understood (O'Shaughnessy, 2009). Germans came to believe that they could continue to exercise their faith while simultaneously supporting the Nazi leadership and the German Christian movement led by Müller. Since the church played a pivotal role in the community, anti-Semitic biases entrenched themselves in the German consciousness (Weber, 2009).

The German Christian movement made momentous changes to German Protestantism and aligned with Nazi racial thought. German Christians initiated a process of classifying people by racial heritage in line with the Nazi approach and classification was not based on whether or not one had converted to Christianity. The situation was severely exacerbated by propaganda slogans such as "Die Juden sind unser Unglück" (The Jews are Our Misfortune). This and similar slogans were displayed on street corners on posters and on banners at Nazi rallies (Weber, 2009: 18). His situation deteriorated to the extent that even church leaders whose parents or grandparents had converted from to Christianity from Judaism were thought of as being Jewish. They were also legally debarred serving in similar roles. In 1934, a Lutheran theologian wrote "Our Protestant churches have welcomed the turning point of 1933 as a gift and miracle of God" thus emphasizing the extent of Hitler's reach. A group of German Christians enforced the removal of non-Aryan clergy so as to illustrate their commitment to the Nazi leadership.

Müller vowed as early as 1934 to purge Protestant churches of all Jewish influences. He resolved to get rid of the Old Testament from the Protestant bible since it was grounded on the Hebrew bible. A group of clerics embraced the in- 
troduction of the Aryan Paragraph into the Church but this led to a rupture as it was a controversial move and eventually to the foundation of a rival Confessing Church which believed that the Church should remain as it was. This state of affairs angered Hitler and almost brought about Müller's fall from power as numerous German Protestant clergy supported the Confessing Church movement, which was at then clearly at odds with the notion that the state should impose itself in Church concerns (Stackelberg \& Winkle, 2002: 167). The Confessing Church maintained that everyone baptized in the Christian faith was indeed a Christian, notwithstanding a person's racial lineage. The members of the Confessing Church also opposed the German Christian movement's deviations from using Holy scriptures as they were. Ironically, the majority of Confessing Church adherents did not object to many of the rudiments of Nazism. In fact numerous people in its rank and file were Nazi Party members. The "German Christians" desired a church entrenched in the idea of German nationhood based on Aryan archetypes.

While roughly sixty percent of Protestant clerics supported the Confessing Church, they restricted their antagonism to defending church traditions against growing Nazi influences. Dietrich Bonhoeffer a German pastor and anti-Nazi dissident, was an important founding member of the Confessing Church. In April 1933, he declared his empathy for Jewish victims of Nazism and contended that National Socialism and Christianity were entirely discordant (Bethge, 2000). He became a central symbol of resistance to Hitler's Nazi Germany and was finally executed for his role in the 1945 Operation Valkyrie, a plot to assassinate Hitler (Metaxas, 2011). Perhaps having his conscience pricked by Müller, Bonhoeffer persisted in his support for Nazism but finally committed suicide in Berlin in 1945, just after Russian troops entered Berlin

By 1937, the NSDAP stance towards recalcitrant Christian clergy intensified and this prompted Müller to attempt to recuperate his backing by permitting the Gestapo to monitor church activities. He also acceded to allow Christian youth groups to combine with the Hitler Youth movement. Nonetheless, limitations were placed on clerics and they were exhorted to be reliable from a political perspective and agree to the notion of the superiority of the Aryan race. Jewish Christian pastors were excluded from their ministry. In addition, the Nazi "Führer Principle" which gave Hitler total control over ecclesiastic matters was accepted and Christ and Christianity were to be viewed as being distinctively Aryan in essence. Accordingly, Protestants in Nazi Germany were paradoxically both believers in Christianity and followers of Nazism.

\section{Nazi Impact on the Roman Catholic Church}

In Nazi Germany, roughly 90 percent of Germans belonged to either Protestant or Catholic churches and they posed a hazard to the Nazi infused Volksgemeinschaft. While Protestants found themselves in diverse camps, Roman Catholics in Germany were united in a single church. Protestants diverged in their religious observances and also held dissimilar political opinions. Numerous Protes- 
tants supported Nazism and referred to themselves as "storm troopers of Jesus Christ" thus attempting to claim a dominant domicile for Protestantism in Hitler's Germany. By contrast, it was generally the case that Catholic priests and bishops were very often overtly hostile towards the Nazis and they attacked racist, anti-Semitic and anti-Christian policies, while in the case of Protestant groups, some clergy would support the Nazis (Eatwell, 1995: 105).

Hitler signed a Reichskonkordat (Reich Concordat) in 1933. This was in essence an accord with the Vatican that obligated the Nazi State to respect the independence of Roman Catholic institutions and simultaneously barred clergy from participating in political affairs (Evans, 2005: 234-235). The Vatican stated in its newspaper L'Osservatore Romano that the concordat should not by any means be viewed in the light of any kind of acceptance of Nazism (Carroll, 1999). It was rather aimed appeasing a regime whose leader, Adolf Hitler strove to portray himself as a Messianic character sent from God to save Germany. In this regard, the leading German philosopher in Germany at this time, Martin Heidegger, who had condemned various Jewish and left wing associates in 1933, supported Nazism and viewed Hitler as a Nietzschean superman. He called for "synthesis between science and the power of the will, between workers and thinkers" (Eatwell, 1995: 117) in a “Third way".

In 1933, Hermann Goering banned all Catholic newspapers in the city of Cologne, mentioning that "political" Catholicism would not be endured but eventually the ban was lifted. In February of the same year Adam Stegerwald, who was a conspicuous politician, was confronted while speaking at a public meeting orchestrated by Christian trade unions and the Catholic Centre Party, and numerous priests were hurt in the melee which followed (Gajewski, 1999).

Hitler as part of his Kirchenkampf (church struggle) sought to attempt to unite the forces in Germany and made a public petition for the Church to negotiate the terms of a new Concordat (Church-State covenant) as he knew the Vatican would find it difficult to decline it, as Catholics would be compromised if they did. Pope Pius XI and his Secretary of State, Cardinal Eugenio Pacelli were thus confronted with a quandary. If they did not negotiate with Hitler, he would definitely publicise his terms and claim that the Vatican was anti-Nazi and filibustering. Pacelli opted for an agreement since he believed such an action would provide a better basis for the protection of both civil and religious rights for Catholics. The Reichskonkordat detached the Roman Catholic Church in Germany and this was considered to be an important move in the fight against the Jewry. There was in fact very remote possibility of not agreeing with Nazi plans as thousands of Catholic Center Party campaigners were in concentration camps by the end of June 1933. The anticipated Concordat was signed in July 1933 and indicated that various undertakings such as for example, education, youth associations and Church rallies would be guaranteed by laws in the Reich. The Church was forced to no longer support the Centre and the Bavarian People's Parties (Gajewski, 1999).

Nevertheless, the Nazis sustained their attacks on Christian churches and re- 
solved to weaken them and from 1935 to the end of 1936, many Catholic clergy and holy sisters were detained on spurious trumped up charges such as currency smuggling and sexual offenses and accused of having degenerate and depraved lifestyles (Longerich, 2015: 382). Goebbels was highly intolerant of Catholic opinions and made a concerted effort to suppress the church and in the process intensified propaganda efforts targeted against it (Evans, 2005: 244). He consequently made good propaganda use of such happenings and broadcasted the trials in his propaganda activities (Thacker, 2009: 189). The result was that limitations were placed on Catholic public meetings, and Catholic pamphlets and journals faced intense suppression. Catholic schools were obligated to lessen time spent on religious instruction and all crucifixes were ordered to be detached from national buildings (Evans, 2005: 239-240). By 1939 it was projected that in excess of 10,000 Catholic schools had been suppressed an additional 3,300 schools had been closed down by Nazi rulings in what was labelled "A black day for the Catholic Rhineland" (Gajewski, 1999). Thus many schools were broken up or converted into public facilities. Hitler wanted the Kirchenkampf to remain in place and he induced Goebbels to intensify the anti-Christian actions (Kershaw, 2008: 382). By 1937 the Nazis decided to eradicate the Protestant church (Longerich, 2012: 223) but this had to be cautiously carried out due to foreign policy trepidations (Longerich, 2015: 334). Pacelli eventually became Pope Pius XII in 1939 but he did not publicly denounce anti-Semitism but condemned Nazi racism in broad terms (Carroll, 1999). Churches throughout Europe were generally silent despite the fact Jews were persecuted and ultimately murdered. While there were Christians in the Churches who demanded that a public stand be made in defence of the Jews, they were domineered by Church leaders who sought to evade any encounter with the Nazi regime (Barnett, 1998).

On October 16, 1943, in excess of 1,200 Jews were detained by German occupational forces in what was the Jewish district of Rome and most of them were taken to Auschwitz to be exterminated. The Holocaust is one of the most dishonorable acts of genocide in contemporary history and it has been assessed that eleven million people were killed of which six million were Jews (Barnett, 1992). The Nazis annihilated roughly two-thirds of all Jews residing in Europe. The failure of the churches to be more effective in their actions played a large part in the slaughter which resulted. The "Holocaust sprang from a predominantly Christian part of the world. In fact, Holocaust historian Doris Bergen notes that approximately 95 percent of Germans at that time were baptized into the Christian faith. Many who declared Jesus as "Lord and Savior" were personally involved in the atrocities" (Bergin, 2000: 48-54).

Pius XII's muteness on the anti-Semitic actions of the Nazis demonstrated his failure as a leader of a major part of the Christian faith. Nonetheless, the Roman Catholic Church did offer shelter to hundreds of Jewish escapees in the Vatican City and in other Church establishments under Vatican control. Such actions were commendable but really very far from adequate (Carroll, 1999) and as the Church leader should have been more willing to defy Hitler and possibly be 
more instrumental in averting the holocaust which then occurred.

\section{Conclusion}

The racial policy which existed in Nazi Germany was based on policies and laws effected in Nazi Germany from 1933-1945. They were based upon the notion of the superiority of the Aryan race. Non-Aryans were considered to be Untermenschen (sub-humans). Such humanly unconscious notions were accepted by Germans who were members of the Protestant and Roman Catholic Churches as they fell victim to the effective Nazi propaganda instruments of the regime which spread the philosophy that one's worth as a human being resided in one's affiliation with a racially demarcated collective assemblage. The Nazis fought to protect what they considered to be their racial purity. In this battle, the churches of the key denominations became easy victims. What was certain was that the Church should be destroyed. In 1941, Martin Bormann, "deputy". Fuhrer, reminded the SS leader Heinrich Himmler that the effect of the Churches had to be eliminated (Spartacus Educational, n.d.). The Nazis taught service and obedience to the Reich and crushed any sense of individualism with their twisted philosophy which was devoid of compassion and respect for others. Why did the German Churches and public in general opt to ignore the sad events that denied liberty to fellow Germans who happened to be of different ethnicities?

The German population blinded by the effective propaganda, became convinced that Hitler was the messiah of Germany. Hitler was able to succeed in extermination human beings in concentration camps because he established effective control over information within German society and also since the fact that in Nazi Germany morality was relativistic, and the survival of the fittest was the only worthy aspect of life. This sentiment sadly rubbed off on the Christian churches, which could have done far more to avert the Holocaust, which ultimately transpired. While people believed they were alive in burgeoning Nazism, they were in spirit dead from a human consciousness perspective even if they were adherents of the Protestant and Catholic churches due to the effectiveness of the propaganda machinery.

\section{References}

Allen, W. S. (1984). The Nazi Seizure of Power: The Experience of a Single German Town, 1922-1945. New York: F. Watts.

Barnett, V. J. (1998). The Role of the Churches in Nazi Germany Compliance and Confrontation. Dimensions, 12, 37-39.

Barnett, V.J. (1992). For the Soul of the People: Protestant Protest against Hitler. New York: Oxford University Press.

Bauz, I., Brüggemann, S., \& Maier, R. (2013). Die Geheime Staatspolizei in Württemberg und Hohenzollern. Stuttgart: Schmetterling.

Beck, H. (2006). Between the Dictates of Conscience and Political Expediency: Hitler's Conservative Alliance Partner and Antisemitism during the Nazi Seizure of Power, Journal of Contemporary History, 41, 611-640. 
https://doi.org/10.1177/0022009406067745

Bennecke, F. (1937). Vom deutschen Volk und seinem Labensraum: Handuch für die Schulung in der HJ. Munich: Franz Eher.

http://www.calvin.edu/academic/cas/gpa/hjhandbuch.htm

Bergin, D. L. (2000). Collusion, Resistance, Silence: Protestants and the Holocaust. In C. Rittner, S. D. Smith, \& I. Steinfeldt (Eds.), The Holocaust and the Christian World, London: Kuperard, 48-54.

Bethge, E. (2000). Dietrich Bonhoeffer: Theologian, Christian, Man for His Times: A Biography (Rev. ed.). Minneapolis, MN: Fortress Press.

Burleigh, M., \& Wippermann, W. (1991). The Racial State: Germany 1933-1945. Cambridge and New York: Cambridge University Press.

Carleton Greene, H. (2003). Daily Telegraph (3rd ed.). The Road to World War II, Kristallnacht, Yale University.

Carroll, J. (1999). The Holocaust and the Catholic Church. The Atlantic. https://www.theatlantic.com/magazine/archive/1999/10/the-holocaust-and-the-catholi c-church/305061/

Chandler Robbins, H. (1938). The Germanisation of the New Testament by Bishop Ludwig Müller and Bishop. London: Weidemann.

Coupe, W. A. (1998). Cartoons of the Third Reich. History Today, 48, 26-32.

Eatwell, R. (1995). Fascism: A History. London: Chatto and Windus.

Evans, R. J. (2005). The Third Reich in Power. New York: Penguin.

Friedlander, S. (1998). Nazi Germany and the Jews: Volume 1: The Years of Persecution 1933-1939. New York, Perennial.

Gajewski, K. J. (1999). Nazi Policy and the Catholic Church. Catholic Education Resource Center.

https://www.catholiceducation.org/en/culture/history/nazi-policy-and-the-catholic-ch urch.html

Gellately, R. (1992). The Gestapo and German Society: Enforcing Racial Policy, 1933-1945. New York: Oxford University Press.

Gilbert, M. (2006). Kristallnacht: Prelude to Destruction. New York: HarperCollins.

Goebbels, J. (1934). Erkenntnis und Propaganda. Signale der neuen Zeit: 25 ausgewählte Reden von Dr. Joseph Goebbels (pp. 28-52). Munich: Zentralverlag der NSDAP. http://www.calvin.edu/academic/cas/gpa/goeb54.htm

Hale, O. J. (1973). The Captive Press in the Third Reich. Princeton, NJ: Princeton University Press.

Heck, A. (1985). Child of Hitler: Germany in the Days When God Wore a Swastika (p. 14). Phoenix: Renaissance House.

Hitler, A. (1971). Mein Kampf (Mannheim, R., Trans., p. 342). Boston: Houghton Mifflin Company.

Holocaust Encyclopedia (2017). Historical Film Footage Goebbels Claims Jews Will Destroy Culture. Nuremberg.

https://www.ushmm.org/wlc/en/media_fi.php?ModuleId=0\&MediaId=192\#

Kershaw, I. (2001). Hitler 1889-1936: Hubris. Hubris, London: Penguin Books Limited.

Kershaw, I. (2008). Hitler: A Biography. New York: W. W. Norton \& Company.

Koonz, C. (2003). The Nazi Conscience. Cambridge, MA: Belknap. 
Lansen, O. (2010). Child of Hitler. LBST 2102. Charlotte, NC: University of North Carolina at Charlotte.

Longerich, P. (2010). Holocaust: The Nazi Persecution and Murder of the Jews. Oxford, New York: Oxford University Press.

Longerich, P. (2012). Heinrich Himmler: A Life. Oxford, New York: Oxford University Press.

Longerich, P. (2015). Goebbels: A Biography. New York: Random House.

Metaxas, E. (2011). Bonhoeffer: Pastor, Martyr, Prophet, Spy. London: Thomas Nelson.

Miller, M. (2006). Leaders of the SS and German Police, Vol. 1. San Jose, CA: R. James Bender Publishing.

Murphy, J. (1939). Mein Kampf(English Trans.). London: Hutchison \& Co. in Association with Hurst \& Blackett, Ltd.

Nazi State (2010). The Hutchinson Unabridged Encyclopedia. http://www.credoreference.com/entry/heliconhe/nazi_state

Noakes, J. (2004). Leaders of the People? The Nazi Party and German Society. Journal of Contemporary History, 39, 190. https://doi.org/10.1177/0022009404042128

O'Shaughnessy, N. (2009). Selling Hitler: Propaganda and the Nazi Brand. Journal of Public Affairs, 9, 55-76. https://doi.org/10.1002/pa.312

Pehle, W. H. (1991). From "Reichskristallnacht” to Genocide. New York: Berg.

Schwab, G. (1990). The Day the Holocaust Began: The Odyssey of Herschel Grynszpan. New York: Praeger.

Snell, J. L. (1959). The Nazi Revolution: Germany's Guilt or Germany's Fate? Boston: Heath \& Co.

Spartacus Educational (n.d.). Jews in Nazi Germany. http://spartacus-educational.com/GERjews.htm

Spielvogel, J. J. (2005). Hitler and Nazi Germany (5th ed., p. 272). Upper Saddle Creek, New Jersey: Pierson Prentice Hall.

Stackelberg, R., \& Winkle, S. A. (2002). The Nazi Germany Sourcebook: An Anthology of Texts. London: Routledge.

Steigmann-Gall, R. (2003). The Holy Reich: Nazi Conceptions of Christianity. Cambridge: Cambridge University Press. https://doi.org/10.1017/CBO9780511818103

Taylor, R. (1998). Film Propaganda: Soviet Russia and Nazi Germany (p. 175). London: I. B. Tauris.

Thacker, T. (2009). Joseph Goebbels: Life and Death. UK: Palgrave Macmillan.

Voigtländer, N., \& Voth, H.-J. (2015). Nazi Indoctrination and Anti-Semitic Beliefs in Germany. Proceedings of the National Academy of Sciences, 112, 7931-7936. http://www.pnas.org/content/112/26/7931.full.pdf https://doi.org/10.1073/pnas.1414822112

Weber, L. (2009). The Holocaust Chronicle. Lincolnwood, IL: Legacy Publishing.

Welch, D. (1993). The Third Reich: Politics and Propaganda. London: Routledge.

Welch, D. (2004). Propaganda and the Volksgemeinschaft: Constructing a People's Community. Journal of Contemporary History, 39, 213-238.

https://doi.org/10.1177/0022009404042129 